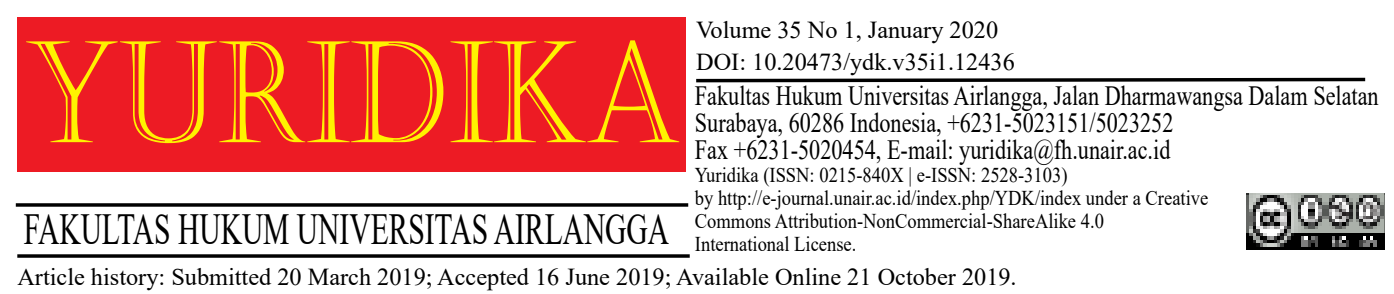

\title{
Implementation of the Doctrine of the Business Judgment Rule on Bankruptcy Law in Indonesia
}

\author{
Andika Wijaya \\ andika.wijaya-2018@fh.unair.ac.id \\ Jonifianto \& Partners Law Office
}

\begin{abstract}
One of the mechanisms that can be taken in resolving accounts payable to a limited liability company in bankruptcy. In the case of bankruptcy due to mistakes made personally by the Board of Directors and the Board of Commissioners, they must be responsible for debts held by limited liability companies. The company law regulates the way for the Board of Directors and Board of Commissioners to avoid liability for losses suffered by the company, through the doctrine of the Business Judgment Rule (BJR). In practice, the application of the BJR doctrine in bankruptcy law is characterized by differences in interpretation between law enforcers. Differences in interpretation occur because there is no clear provision in the Republic of Indonesia Law Number 37 of 2004 concerning Bankruptcy and Delay of Obligations to Pay Debt (Law No. 37/2004) which limits the filing of bankruptcy applications to the personal Directors and Board of Commissioners. The research in this article is carried out by reform-oriented research methods, to make changes to Law No. 37/2004 to clarify the application of the BJR doctrine in bankruptcy law in Indonesia. With the implementation of legal reform, it is expected that there will be no difference in interpretation regarding the application of the BJR doctrine to bankruptcy law at the Commercial Court in Indonesia.
\end{abstract}

Keywords: Bankruptcy; Business Judgement Rule; Limited Liability Company.

\section{Introduction}

The solution to the problem of limited liability debt through a well-known bankruptcy method in the doctrine is called commercial exit from financial distress. Bankruptcy, in this case, is a way out for the company from financial problems that cannot be overcome.1 Bankruptcy can be a way for financial distress, whose

\footnotetext{
1 Ricardo Simanjuntak, 'Kepailitan dan Likuidasi', Studi Kasus : BPPN vs PT Muara Alas Prima (2005) in M. Hadi Shubhan, Hukum Kepailitan : Prinsip, Norma, Dan Praktik Di Pengadilan (Kencana 2015).[63].
} 
characteristics include: poor company performance, loss of market share, and tend to be in a position to survive any economic changes. ${ }^{2}$ The term financial distress can be understood as a situation where the cash flow of the business results of a company is unable to fulfill its debt payment obligations. ${ }^{3}$

Two ways can be taken to make the company declared bankrupt by the Commercial Court, among others, by filing a bankruptcy application by the company itself (voluntary bankruptcy), or through filing a request for bankruptcy by involuntary bankruptcy. Submission of bankruptcy by yourself (voluntary bankruptcy) is a type of bankruptcy where an insolvent debtor brings a petition to the Court to request that he (both individuals and legal entities) be declared bankrupt. ${ }^{4}$ Bankruptcy by other people (involuntary bankruptcy) is a type of bankruptcy that occurs due to the presence of someone or more Creditors petitioning the Court with a request that the Debtor is declared bankrupt. ${ }^{5}$

The requirement that the bankruptcy petition can be granted by the Court is stipulated in article 2 paragraph 1 of the Republic of Indonesia Law Number 37 of 2004 concerning Bankruptcy and Delay of Obligation to Pay Debt (hereinafter abbreviated as Law No. 37/2004), including: having at least two a creditor, and does not pay at least one debt that is due and can be collected. If the bankruptcy application is granted by the Court, by law, the Debtor loses the right to control his assets. Mastery of the Debtor's assets turned to the Curator. After the bankruptcy decision is pronounced by the Commercial Court, the Curator or the Heritage Office will carry out the assignment by way of liquidating bankrupt assets, followed by the distribution of proceeds from the sale of bankrupt assets (after deducting bankrupt assets costs and debts). ${ }^{6}$ The procedure for the distribution of proceeds from the sale of bankrupt assets, in this case, is carried

\footnotetext{
2 John Y. Campbell, 'Predicting Financial Distress and the Performance of Distressed Stocks' (2010) IX Journal of Investment Management of Harvard University.[1].

3 Suroso, 'Investasi Pada Perusahaan Yang Menghadapi Financial Distres' (2006) XXXV Manajemen Usahawan Indonesia.[7].

4 Julia Kagan, 'Voluntary Bankruptcy' (2018) < https://www.investopedia.com/terms/v/voluntary-bankruptcy.asp> accessed 27 February 2019.

${ }^{5}$ ibid.

${ }^{6}$ M.N. Purwosutjipto, Pengertian Pokok Hukum Dagang Indonesia 8 : Perwasitan, Kepailitan Dan Penundaan Pembayaran (Djambatan 1992).
} 
out in accordance with the principles of parity crematorium, the principle of pari passu pro rata parte and the principle of structured creditors, as stipulated in article 1131 and article 1132 Indonesian Civil Law. ${ }^{7}$

Bankruptcy that occurs in a limited liability company can occur, either because of an error made by the company's organs (Directors and Commissioners) or because of the financial condition of the company that is no longer able to pay all debts to the Creditors. If the loss of the company that causes it to go bankrupt is caused by an error from the personal Directors and Commissioners (ultra vires), they must bear the losses suffered by the company. To avoid liability based on ultra vires allegations, members of the Board of Directors and the Board of Commissioners can take refuge behind the doctrine of the Business Judgment Rules (abbreviated as BJR).

The doctrine of the Business Judgment (abbreviated as BJR) is one of the fundamental doctrines of the law of limited liability companies. The BJR is basically the most important legal assessment standard in corporate law, to protect the Board of Direction from lawsuits, unless it can be proven sufficiently that the Board has violated the tasks mandated to him or if the decision making process those taken have violated the principle of independence and the principle of avoiding personal interests. ${ }^{8}$ BJR is a legal doctrine that protects the Director from personal liability for corporate decisions he has made. ${ }^{9}$ According to Nindyo Pramono, the BJR doctrine provides legal protection for the personal Directors of all decisions, policies and business transactions that cause harm to the corporation they lead, as long as it is carried out in good faith, prudently, and by the authority and responsibilities of the Directors. ${ }^{10}$

${ }^{7}$ M. Hadi Shubhan (n 1).

${ }^{8}$ Bernard S. Sharfman, 'The Importance of the Business Judgment Rule' (2017) 14 New York University Journal of Law and Business < https://papers.ssrn.com/sol3/papers.cfm?abstract_ $\mathrm{id}=2888052>$.

${ }^{9}$ Lori McMillan, 'The Business Judgment Rule as an Immunity Doctrine' (2013) 4 William \& Mary Business Law Review.[125]

${ }_{10}$ Nindyo Pramono, 'Beauty Contest Sebagai Business Judgement versus Persaingan Usaha Tidak Sehat' (Hukum Online, 2012) < https://www.hukumonline.com/berita/baca/lt4fcc591579b3e/ ibeauty-contest-i-sebagai-ibusiness-judgement-i-versus-persaingan-usaha-tidak-sehat-broleh--profdr-nindyo-pramono-sh--ms-> accessed 21 February 2019. 
The application of the BJR doctrine in bankruptcy law in Indonesia still contains confusion because of the different interpretations of law enforcers. This can be exemplified in the case of the Supreme Court Decision Number 01 PK/N/2004 read out in a public hearing on March 23, 2004, namely in a case between PT Karunia Wana Ika Wood Industrial and Tobeng Mahatani (as Debtors and Directors of Debtors) against PT Wijaya Indah Permai (as Creditors). The decision of the Supreme Court Number 01 PK N/2004 dated March 23, 2004, has revoked the Decision of the Supreme Court Number 030 K/N/2003 dated November 20, 2003, stating that PT Karunia Wana Ika Wood Industrial and Tobeng Mahatani went bankrupt with all legal consequences.

Furthermore, against the Decision of the Supreme Court Number 030 K/N/2003 dated November 20, 2003, a legal review has been done. The Panel of Judges at the level of review argued by citing article 82 of Act No. 1 of 1995, that accountability for Tobeng Mahatani could not be requested for actions carried out in capacity as a party representing PT Karunia Wana Ika Wood Industrial, both inside and outside the court. ${ }^{11}$ The Panel of Judges in this matter considered the Judges in the appeal court had made a serious mistake, namely imposing personal responsibility on Tobeng Mahatani, as the President Director of PT Karunia Wana Ika Wood Industrial, even though the responsibility should only be borne by PT Karunia Wana with Law Number 1 of $1995 .{ }^{12}$ Furthermore, the Panel of Judges in the review stage read out the decision stating that they refused the bankruptcy request from PT Wijaya Indah Permai (Creditors).

The above case example is proof of the different interpretations between the Panel of Judges in Case No. 030 K/N/2003 with the Panel of Judges on Case No. $01 \mathrm{PK} / \mathrm{N} / 2004$. This difference in interpretation occurs because there is no clear norm (there is a legal vacuum) regarding the application of the BJR doctrine in

${ }^{11}$ Mahkamah Agung Republik Indonesia, Himpunan Putusan Yang Telah Berkekuatan Hukum Tetap (Judge Made Law) Dalam Bidang Khusus Perkara Kepailitan Mahkamah Agung Republik Indonesia (Mahkamah Agung Republik Indonesia 2010).[55].

12 ibid. 
bankruptcy law in Indonesia. Law No. 37/2004 does not regulate how the process of filing a bankrupt application to a limited liability company conducts an ultra vires action. Thus, there is a legal vacuum in Law No. 37/2004 concerning the application of the BJR doctrine in bankruptcy of limited liability companies.

Problems regarding the legal vacuum in the application of the BJR doctrine to the bankruptcy law of limited liability companies in Law No.37/2004 were examined using reform-oriented research. According to Hutchinson, research using a reformoriented research model is research which intensively evaluates the adequacy of existing rules and which recommends changes to any rules found wanting. ${ }^{13}$

Reform-oriented research is carried out using the statue approach and conceptual approach. The law approach is carried out by analyzing relevant laws (as primary legal material), especially Law No. 37/2004 and Law of the Republic of Indonesia Number 40 of 2007 concerning Limited Liability Companies (abbreviated as Law No. 40/2007). The conceptual approach is made by gathering legal concepts about BJR delivered by legal experts in secondary legal materials, both in the form of books and journals. Collection of legal materials is done through library research. Through the collection of rules that are going to be reformed, an analysis is carried out, which will subsequently bring up recommendations for a legal vacuum in the application of the BJR doctrine to Law No. 37/2004. The formulation of recommendations forms the basis of conclusions in this article.

\section{The Doctrine of Business Judgment Rules}

BJR is a doctrine stating that a decision was taken by the Board of can't be blamed, even though the decision turned out to be detrimental to the Company. ${ }^{14}$ Born from the Anglo Saxon legal tradition (applied among others in England and Wales), BJR is understood as a doctrine where the Court is subject to business

\footnotetext{
13 Peter Mahmud Marzuki, Penelitian Hukum (Kencana 2011).[32].

${ }^{14}$ Sartika Nanda Lestari, 'Business Judgment Rule Sebagai Immunity Doctrine Bagi Direksi Badan Usaha Milik Negara Di Indonesia' (2015) 8 Notarius.[305-306].
} 
decisions taken by the Board of Directors, and the decision is legally protected. ${ }^{15}$ The court must not hesitate to protect the Directors who have issued decisions, because he has been protected by the doctrine of the business judgment rule. ${ }^{16}$ Because it is protected by the BJR doctrine, the Company's Directors do not need to feel anxious or worried in making business decisions, because the BJR doctrine legally provides protection so that actions in the form of business decisions cannot be sued in the Court, even though the decision ultimately harms the Company and third parties concerned. ${ }^{17}$

Ada several conditions that must be fulfilled by the Board of Directors to avoid personal liability for losses suffered by the Company for the business decisions it takes, including: ${ }^{18}$

1. Business decisions are based on applicable legal provisions;

2. Business decisions are carried out by referring to good intentions;

3. Business decisions are made with the right objectives;

4. Business decisions are based on reasonable reasons;

5. Business decisions are carefully determined;

6. Business decisions are carried out in a trusted way as the best decision.

In principle, the BJR doctrine has differences with other doctrines that govern the responsibilities of the Directors, such as ultra vires doctrine, piercing the corporate veil, fiduciary duty, and others. According to Munir Fuady, the BJR doctrine has a role in protecting actions taken by the Board of Directors within the legal framework of the company, where the Court can test it by using existing legal regulations. ${ }^{19}$ The application of the BJR doctrine is closely related to the position of the Board of Directors as the most professional and most authorized

\footnotetext{
${ }^{15}$ Andrew Keay and Joan Loughrey, 'The Concept of Business Judgment' (2019) 39 Legal Studies.[36-55].

${ }^{16}$ Kurniawan, 'Tanggung Jawab Direksi Dalam Kepailitan Perseroan Terbatas Berdasarkan Undang-Undang Perseroan Terbatas' (2012) 24 Mimbar Hukum < https://jurnal.ugm.ac.id/jmh/article/view/16126>.[219].

${ }^{17}$ Siti Hapsah Isfardiyana, 'Business Judgement Rule Oleh Direksi Perseroan’ (2017) 2 Panorama Hukum.[16].

18 Munir Fuady, Doktrin-Doktrin Modern Dalam Corporate Law Dan Eksistensinya Dalam Hukum Indonesia (Citra Aditya Bakti 2014).[186].

19 ibid.
} 
party to make the best decisions for the interests of the company. ${ }^{20}$ The Board of Directors is essentially an organ specifically representing the interests of the Company, different from the General Meeting of Shareholders, which is an organ that represents the interests of the shareholders. The Board of Directors must serve the interests of the Company, not to the interests of one major shareholder or all shareholders. ${ }^{21}$

The BJR doctrine is used by the Court to test whether the decision of the Board of Directors has been by or even violates existing legal regulations, not to assess the suitability of a business decision..$^{22}$ For this reason, a lawsuit against the Board of Directors based on arguments about the error of a business decision is often rejected, because the court must respect a business decision taken by the Board of Directors who are generally people who understand and are experienced in the business field. ${ }^{23}$ By the BJR doctrine, the Court can only test a business decision on the compliance of the Board of Directors based on applicable laws and regulations (legal aspects), not on business/economic aspects.

The BJR doctrine is a doctrine that applies to the law of limited liability companies in Indonesia. In its history, the application of the BJR doctrine can be read from Forumbankarrest on January 21, 1955, wherein one arrest (Decision of Hoge Raad the Netherlands) it was confirmed that in giving business decisions, the Board of Directors could override RUPS (General Meeting of Shareholders) instructions, the Board of Commissioners and any institution, as long as the Board of Directors exercised authority and its duties are based on the laws and articles of association of the Company. ${ }^{24}$ This doctrine was then also applied in article 97 paragraph 5 of the Republic of Indonesia Law Number 40 of 2007 concerning Limited Liability Companies (hereinafter abbreviated as Law Number 40 of 2007), which determines

\footnotetext{
20 ibid.

${ }^{21}$ Fred. B.G. Tumbuan, Himpunan Mengenai Beberapa Produk Legislasi Dan Masalah Hukum Di Bidang Hukum Perdata (Gramedia Pustaka Utama 2017).[99].

22 ibid.

${ }^{23}$ Munir Fuady (n 18).Op.Cit.[187].

${ }^{24}$ Fred. B.G. Tumbuan (n 21).Op.Cit.[101].
} 
matters that are the reason for the release of the Board of Directors' liability for losses suffered by the Company, including:

a. If the loss is not caused by an error or negligence;

b. If the Board of Directors has taken action in managing the Company in good faith and prudence for the sake of interest, and in line with the purposes and objectives of the Company;

c. If the Board of Directors does not have a conflict of interest, either directly or indirectly against the measurement actions that have caused losses to the Company;

d. If the Board of Directors has acted to prevent further losses from arising.

The BJR doctrine in the legal context of a limited liability company is adjacent to other doctrines, namely: piercing the corporate veil. ${ }^{25}$ The doctrine of piercing the corporate veil (abbreviated as PCV) is a doctrine that regulates the responsibility of a person or several people for legal actions committed by a company (legal entity). ${ }^{26}$ This is explained in article 97 paragraph 3 of the Law Number 40 of 2007, namely that the Board of Directors is personally responsible for the losses suffered by the company if the concerned person is negligent or making mistakes in carrying out tasks. ${ }^{27}$

The PCV doctrine can be a balancing counterweight to the BJR doctrine. Despite being able to take refuge behind the BJR doctrine, a Board of Directors can be held accountable through the PCV doctrine. Associated with the sound of article 95 paragraph 5 of the Law Number 40 of 2007, as long as the Directors (as business decision-makers) do not fulfill the elements, so long as the Directors can take refuge behind the BJR doctrine. However, if the elements as Article 95 paragraph 5 of the Law Number 40 of 2007 are fulfilled, the Board of Directors can be held personally responsible for the losses suffered by the company based on the PCV doctrine. If the Board of Directors consists of more than 1 (one) person, the responsibility for losses suffered by the company must be borne jointly or jointly. The principle of joint accountability is basically aimed at giving a warning to each

\footnotetext{
${ }^{25}$ Yahya Harahap, Hukum Perseroan Terbatas (Sinar Grafika 2013).[413].

${ }^{26}$ Munir Fuady (n 18).Op.Cit.[7].

27 Rudhy Prasetya, Perseroan Terbatas Teori Dan Praktik (Sinar Grafika 2014).[23].
} 
member of the Board of Directors to truly act competently, responsibly, and fully in good faith in running the company's business. ${ }^{28}$

\section{Application of the BJR Doctrine in Indonesian Bankruptcy Law}

The BJR doctrine is applied to determine the Directors' responsibility for the losses suffered by the Company. The burden of accountability can be borne by the Board of Directors of the results of liquidation of bankrupt assets by the Curator or the Heritage House are not enough to pay off all of the company's debts. In this case, it must be proven whether the Board of Directors has made a mistake or negligence which caused the Company to suffer losses resulting in bankruptcy.

The party that must prove the accountability of the Board of Directors, which due to their mistakes or negligence has made the Company bankrupt is a postulating party. ${ }^{29}$ If the party arguing has succeeded in proving, each member of the Board of Directors of the company is legally responsible jointly for losses due to the bankruptcy of the Company that is not covered by all of the Company's assets. ${ }^{30}$ Each member of the Board of Directors can take refuge behind the BJR doctrine to give up personal responsibility for the losses suffered by the Company.

Referring to the Law Number 40 of 2007, there are several parties who can sue the accountability of members of the Board of Directors regarding errors and/ or omissions that cause losses to the Company, namely:

a. Shareholders representing at least $1 / 10$ part of the total shares with voting rights (vide article 97 paragraph 6);

b. Other members of the Board of Directors (vide article 97 paragraph 7);

c. Members of the Board of Commissioners (vide article 97 paragraph 7);

d. Third-party (vide article 104 paragraph 5);

e. Prosecutor, for the public interest (vide article 138 paragraph 3 letter a).

Submitting a lawsuit against a member of the Board of Directors who is suspected of committing a mistake and negligence that caused a loss to the Company is done

${ }^{28}$ Yahya Harahap (n 25).[414].

${ }^{29}$ Fred. B.G. Tumbuan, Tanggung Jawab Direksi Sehubungan Dengan Kepailitan Perseroan Terbatas; Rudhy A. Lontoh, Penyelesaian Utang Piutang Melalui Pailit Atau Penundaan Kewajiban Pembayaran Utang (Alumni 2001).[295].

30 ibid. 
by registering it with the District Court. This is explicitly determined by article 97 , paragraph 6 of the Law Number 40 of 2007.

A Board of Directors from a Limited Liability Company can be required to be responsible for losses suffered by the Company, if the Company is declared bankrupt and, bankrupt assets are insufficient to pay all debts to the Creditors. Article 104 paragraph 2 of the Law Number 40 of 2007 states:

"In the event that the bankruptcy as referred to in paragraph (1) occurs due to a mistake or negligence of the Board of Directors and insolvent assets that are insufficient to pay all the obligations of the Company in bankruptcy, each member of the Board of Directors is jointly responsible for all obligations that are not repaid from the bankrupt assets".

The application of the BJR doctrine is related to the personal responsibility of the Board of Directors for errors and/or negligence that caused the bankruptcy of the Company stated in article 104 paragraph 4 of the Law Number 40 of 2007, which states that members of the Board of Directors are not responsible for bankruptcy of the Company:

1. If bankruptcy occurs not because of an error and negligence;

2. If the Board of Directors has managed in good faith, prudence, and full responsibility for the interests of the Company, and in line with the purposes and objectives of the Company;

3. If the Board of Directors does not have a conflict of interest either directly or indirectly with the management action taken; and

4. If the Board of Directors has taken action to prevent bankruptcy.

To demand personal accountability of the Board of Directors for the bankruptcy of the Company caused by errors or negligence, the Plaintiffs can submit through the District Court, cannot submit directly through the Commercial Court. This is closely related to the concept of evidentiary law in bankruptcy that implements proof in a simple (concise) manner. Article 8 paragraph 4 of the Law Number 37 of 2004 determines that a bankrupt application must be granted in the event that there are facts or conditions that are simply proven where the requirements for bankruptcy under Article 2 paragraph (1) have been fulfilled. A bankruptcy application can be granted if there is an event (summary) that shows an event or 
condition that indicates that the debtor is in an insolvent condition (unable to pay). ${ }^{31}$ In the case of demands regarding the personal accountability of the Directors of the Company that have been declared bankrupt, the party requesting a bankruptcy statement must prove the existence of a debt that the Debtor cannot deny. ${ }^{32}$ The burden of proof, in this case, is borne by Bankruptcy Applicants (both Creditors and Debtors) to be able to prove the existence of 'facts or the existence of elements of article 2 paragraph 1 in a simple manner. ${ }^{33}$ They claim to ask the Board of Directors for personal accountability for the bankruptcy of the Company, in this case, will be difficult to implement concisely through the Commercial Court. Because the lawsuit regarding the Directors' responsibility is more focused on the actions of the Board of Directors which due to their mistakes or negligence caused the Limited Liability Company to be declared bankrupt. The proof of concept in article 8 paragraph 4 of the Law Number 37 of 2004 focuses more on events and circumstances regarding the minimum requirements of two Creditors and one bill that has fallen tempo. Since the proof of the Directors' mistakes and negligence is not in line with the provisions of Article 8 paragraph 4 of the Law Number 37 the Year 2004, the claim of the Company's bankruptcy cannot be made through the Commercial Court.

To be able to ask for personal accountability from the Board of Directors regarding bankruptcy of a Limited Liability Company, the plaintiff(both Shareholders representing 1/10 part of the total shares with voting rights, other Directors, Board of Commissioners, Third Parties and/or Prosecutors, for the public interest) must first use the inspection mechanism against the Company. Article 138 paragraph 1 of the Law of the Number 40 of 2007, states: Examination of the Company can be carried out to obtain data or information if there are allegations that:

1. The Company commits an unlawful act that harms shareholders or third parties; or 2. Members of the Board of Directors or Board of Commissioners commit acts that

\footnotetext{
${ }^{31}$ M.N. Purwosutjipto (n 6).Op.Cit.[32].

${ }^{32}$ Kartini Muljadi and Gunawan Widjaja, Pedoman Menangani Perkara Kepailitan (Raja Grafindo Persada 2005).[135].

33 Andika Wijaya, Penanganan Perkara Kepailitan Dan Penundaan Pembayaran Secara Praxis (Citra Aditya Bakti 2017).[49].
} 
violate the law that harms the Company or shareholders or third parties.

Requests for the examination of the Company as above are submitted through the District Court (vide article 138 paragraph 2 of the Republic of Indonesia Law Number 40 of 2007 concerning Limited Liability Companies). Furthermore, in the trial, the Chairperson of the District Court will provide a determination of the examination by raising a maximum of three experts to examine in order to obtain the necessary data or information. ${ }^{34}$ For the work that has been done, the Experts will submit a report to the chairman of the District Court, and then a copy of the results of the examination will be submitted to the Applicant. ${ }^{35}$ From the results of the examination, the Applicant can determine his further attitude to the Company. ${ }^{36}$ If from the results of the examination it is found that there is an element of error and/ or negligence of the Board of Directors which caused the Company to go bankrupt, then based on Article 104 paragraph 2 of the Law Number 40 of 2007, the results of the examination can be used by the Applicant to submit a statement of bankruptcy to the Commercial Court.

\section{Conclusion}

Submitting a bankruptcy application for the personal Director and the Board of Commissioners based on ultra vires cannot be submitted before the company's inspection procedure as stipulated in article 138 paragraph 2 of the Republic of Indonesia Law Number 40 of 2007 concerning Limited Liability Companies. The results of the company's inspection form the basis for demanding bankruptcy on the personal Director and the Board of Commissioners. If the bankruptcy application of the Director and the Board of Commissioners is based on ultra vires is not accompanied by the results of the company's inspection legalized by the District Court, the bankruptcy application must be declared unacceptable because the application is premature.

\footnotetext{
${ }^{34}$ See article 139 paragraph 3 of the Law Number 40 of 2007.

35 See article 140 of the Law Number 40 of 2007.

${ }^{36}$ See explanation of article 140 paragraph 2 of the Law Number 40 of 2007.
} 
The Law Number 37 of 2004 needs to be reformed by including provisions that limit creditors' rights or other parties to submit bankruptcy applications to the personal Directors and Board of Commissioners based on ultra vires. Submitting a bankruptcy application to the personal of Directors and Board of Commissioners can only be made based on the results of the company's inspection obtained from submitting an application to the District Court corresponding The Law Number 40 of 2007. For the bankruptcy application that was not accompanied by the results of the company's inspection, the Commercial Court must declare it not authorized to examine the case.

\section{Bibliography}

Andika Wijaya, Penanganan Perkara Kepailitan Dan Penundaan Pembayaran Secara Praxis (Citra Aditya Bakti 2017).

Andrew Keay and Joan Loughrey, 'The Concept of Business Judgment' (2019) 39 Legal Studies.

Bernard S. Sharfman, 'The Importance of the Business Judgment Rule' (2017) 14 New York University Journal of Law and Business $<$ https://papers.ssrn.com/ sol3/papers.cfm?abstract_id $=2888052>$.

Fred. B.G. Tumbuan, Himpunan Mengenai Beberapa Produk Legislasi Dan Masalah Hukum Di Bidang Hukum Perdata (Gramedia Pustaka Utama 2017).

John Y. Campbell, 'Predicting Financial Distress and the Performance of Distressed Stocks’ (2010) IX Journal of Investment Management of Harvard University.

Julia Kagan, 'Voluntary Bankruptcy' (2018) <https://www.investopedia.com/ terms/v/voluntary-bankruptcy.asp $>$ accessed 27 February 2019.

Kartini Muljadi and Gunawan Widjaja, Pedoman Menangani Perkara Kepailitan (Raja Grafindo Persada 2005).

Kurniawan, 'Tanggung Jawab Direksi Dalam Kepailitan Perseroan Terbatas Berdasarkan Undang-Undang Perseroan Terbatas' (2012) 24 Mimbar Hukum $<$ https://jurnal.ugm.ac.id/jmh/article/view/16126>.

Law Number 37 the Year 2004 Concerning Bankruptcy and Postponement of Debt Payment Obligations (The Republic of Indonesia State Gazette Year 2004 Number 131, Annotation 4443). 
Law Number 40 the Year 2007 Concerning Limited Liability Company (The Republic of Indonesia State Gazette Year 207 Number 106, Annotation 4756).

Lori McMillan, 'The Business Judgment Rule as an Immunity Doctrine' (2013) 4 William \& Mary Business Law Review.

M. Hadi Shubhan, Hukum Kepailitan : Prinsip, Norma, Dan Praktik Di Pengadilan (Kencana 2015).

M.N. Purwosutjipto, Pengertian Pokok Hukum Dagang Indonesia 8 : Perwasitan, Kepailitan Dan Penundaan Pembayaran (Djambatan 1992).

Mahkamah Agung Republik Indonesia, Himpunan Putusan Yang Telah Berkekuatan Hukum Tetap (Judge Made Law) Dalam Bidang Khusus Perkara Kepailitan Mahkamah Agung Republik Indonesia (Mahkamah Agung Republik Indonesia 2010).

Munir Fuady, Doktrin-Doktrin Modern Dalam Corporate Law Dan Eksistensinya Dalam Hukum Indonesia (Citra Aditya Bakti 2014).

Nindyo Pramono, 'Beauty Contest Sebagai Business Judgement versus Persaingan Usaha Tidak Sehat' (Hukum Online, 2012) < https://www.hukumonline.com/ berita/baca/lt4fcc591579b3e/ibeauty-contest-i-sebagai-ibusiness-judgementi-versus-persaingan-usaha-tidak-sehat-broleh--prof-dr-nindyo-pramono-sh-ms-> accessed 21 February 2019.

Peter Mahmud Marzuki, Penelitian Hukum (Kencana 2011).

Rudhy A. Lontoh, Penyelesaian Utang Piutang Melalui Pailit Atau Penundaan Kewajiban Pembayaran Utang (Alumni 2001).

Rudhy Prasetya, Perseroan Terbatas Teori Dan Praktik (Sinar Grafika 2014).

Sartika Nanda Lestari, 'Business Judgment Rule Sebagai Immunity Doctrine Bagi Direksi Badan Usaha Milik Negara Di Indonesia’ (2015) 8 Notarius.

Siti Hapsah Isfardiyana, 'Business Judgement Rule Oleh Direksi Perseroan' (2017) 2 Panorama Hukum.

Suroso, 'Investasi Pada Perusahaan Yang Menghadapi Financial Distres' (2006) XXXV Manajemen Usahawan Indonesia.

Supreme Court PK Decision Number 01 PK/N/2004 dated March 23, 2004.

Yahya Harahap, Hukum Perseroan Terbatas (Sinar Grafika 2013).

HOW TO CITE: Andika Wijaya, 'Implementation of the Doctrine of the Business Judgment Rule on Bankruptcy Law in Indonesia' (2020) 35 Yuridika. 